\title{
Ensiling as biological pretreatment of grass (Festulolium Hykor): The effect of composition, dry matter, and inocula on cellulose convertibility
}

Ambye-Jensen, Morten; Johansen, Katja Salomon; Didion, Thomas; Kádár, Zsófia; Schmidt, Jens Ejbye; Meyer, Anne S.

Published in:

Biomass \& Bioenergy

Link to article, DOI:

10.1016/j.biombioe.2013.08.015

Publication date:

2013

Document Version

Early version, also known as pre-print

Link back to DTU Orbit

Citation $(A P A)$ :

Ambye-Jensen, M., Johansen, K. S., Didion, T., Kádár, Z., Schmidt, J. E., \& Meyer, A. S. (2013). Ensiling as biological pretreatment of grass (Festulolium Hykor): The effect of composition, dry matter, and inocula on cellulose convertibility. Biomass \& Bioenergy, 58, 303-312. https://doi.org/10.1016/j.biombioe.2013.08.015

\section{General rights}

Copyright and moral rights for the publications made accessible in the public portal are retained by the authors and/or other copyright owners and it is a condition of accessing publications that users recognise and abide by the legal requirements associated with these rights.

- Users may download and print one copy of any publication from the public portal for the purpose of private study or research.

- You may not further distribute the material or use it for any profit-making activity or commercial gain

- You may freely distribute the URL identifying the publication in the public portal 


\section{AUTHOR QUERY FORM}

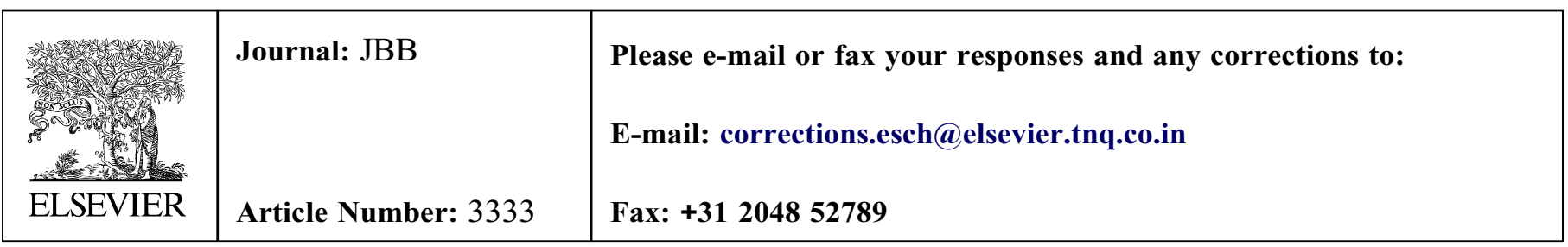

Dear Author,

Please check your proof carefully and mark all corrections at the appropriate place in the proof (e.g., by using on-screen annotation in the PDF file) or compile them in a separate list. Note: if you opt to annotate the file with software other than Adobe Reader then please also highlight the appropriate place in the PDF file. To ensure fast publication of your paper please return your corrections within 48 hours.

For correction or revision of any artwork, please consult http://www.elsevier.com/artworkinstructions.

Any queries or remarks that have arisen during the processing of your manuscript are listed below and highlighted by flags in the proof.

\begin{tabular}{|c|l|}
\hline $\begin{array}{c}\text { Location } \\
\text { in article }\end{array}$ & \multicolumn{1}{c}{$\begin{array}{c}\text { Query / Remark: Click on the Q link to find the query's location in text } \\
\text { Please insert your reply or correction at the corresponding line in the proof }\end{array}$} \\
\hline $\mathbf{Q 1}$ & $\begin{array}{l}\text { As Refs. [3] and [28] were identical, the latter has been removed from the reference list and subsequent } \\
\text { references have been renumbered. } \\
\text { Please confirm that given names and surnames have been identified correctly. }\end{array}$ \\
$\begin{array}{l}\text { Please check this box or indicate } \\
\text { your approval if you have no } \\
\text { corrections to make to the PDF file }\end{array}$ \\
\hline
\end{tabular}

Thank you for your assistance. 


\section{Highlights}

- Ensiling is studied as a pretreatment for cellulolytic conversion of grass.

- Ensiling is shown to improve enzymatic cellulose convertibility of grass.

- Low dry matter improved the ensiling process for organic acids production.

- High levels of lactic acid after ensiling improved enzymatic cellulose conversion.

- Grass composition prior to ensiling affected ensiling and cellulose convertibility.

0961-9534/\$ - see front matter ( 2013 Published by Elsevier Ltd. http://dx.doi.org/10.1016/j.biombioe.2013.08.015

Please cite this article in press as: Ambye-Jensen M, et al., Ensiling as biological pretreatment of grass (Festulolium Hykor): The effect of composition, dry matter, and inocula on cellulose convertibility, Biomass and Bioenergy (2013), http://dx.doi.org/ 10.1016/j.biombioe.2013.08.015 


\title{
Ensiling as biological pretreatment of grass (Festulolium Hykor): The effect of composition, dry matter, and inocula on cellulose convertibility
}

\author{
Q2 $\perp^{\text {Morten Ambye-Jensen }}{ }^{a}, \perp^{K a t j a}$ S. Johansen ${ }_{\perp}^{b}, \perp^{T h o m a s ~ D i d i o n ~}{ }_{\perp}^{c}$,

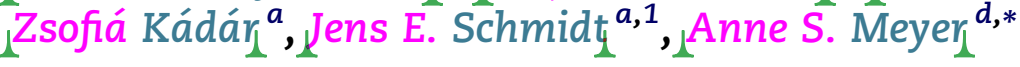 \\ ${ }^{a}$ Department of Chemical and Biochemical Engineering, Technical University of Denmark, Ris $\varnothing$ Campus, \\ Frederiksborgvej 399, Building 301, DK-4000 Roskilde, Denmark \\ ${ }^{\mathrm{b}}$ Novozymes A/S, Krogshøjuej 36, DK-2880 Bagsucerd, Denmark \\ ${ }^{c}$ Danish Plant Breeding Research Division, DLF TRIFOLIUM A/S, Højerupvej 31, DK-4660 Store Heddinge, Denmark \\ ${ }^{d}$ Center for BioProcess Engineering, Department of Chemical and Biochemical Engineering, Building 229, Technical \\ University of Denmark, DK-2800 Lyngby, Denmark
}

\section{A R T I C L E I N F O}

Article history:

Received 27 December 2012

Received in revised form

7 July 2013

Accepted 2 August 2013

Available online xxx

Keywords:

Ensiling

Grass

Biomass characterisation

Enzymatic hydrolysis

Cellulose convertibility

\begin{abstract}
A B S T R A C T
Grass biomass is a prospective type of lignocellulosic biomass for bioenergy and fuel production, but the low dry matter in grass at harvest calls for new pretreatment strategies for cellulosic conversion. In this study, ensiling was tested as a biological pretreatment method of the high yielding grass variety Festulolium Hykor. The biomass was harvested in four cuts over a growing season. Three important factors of ensiling: biomass composition, dry matter (DM) at ensiling, and inoculation of lactic acid bacteria, were assessed in relation to subsequent enzymatic cellulose hydrolysis. The organic acid profile after ensiling was dependant on the composition of the grass and the DM, rather than on the inocula. High levels of organic acids, notably lactic acid, produced during ensiling improved enzymatic cellulose convertibility in the grass biomass. Ensiling of less mature grass gave higher convertibility. Low DM at ensiling $(<25 \%)$ resulted in the highest cellulose convertibilities, which ranged from 32 to $20 \%$ of the available cellulose in the four cuts after ensiling. The study confirms that ensiling can enhance cellulose convertibility of green biomass, and provides new insight to ensiling as a biological pretreatment method for green biomass conversion.
\end{abstract}

(c) 2013 Published by Elsevier Ltd.

\section{Introduction}

Grassland biomass may become an important low cost lignocellulosic raw material for fuels and chemicals in the future, as grassland covers about $69 \%$ of the world's agricultural area [1,2]. Additionally, grassland biomass may add significant ecological value, including protection against soil erosion and habitat creation [2]. Cultivation of temperate grass allows for several harvests ( $2-4$ cuts) during a season contributing to the high yield. It is well known that the

\footnotetext{
* Corresponding author. Tel.: +45 45252800 .

E-mail address: am@kt.dtu.dk (A.S. Meyer).

${ }^{1}$ Present address: Masdar Institute, Chemical Engineering Program, PO BOX 54225, Abu Dhabi, United Arab Emirates. 0961-9534/\$ - see front matter @ 2013 Published by Elsevier Ltd. http://dx.doi.org/10.1016/j.biombioe.2013.08.015
} 
chemical composition of grass changes between cuts over the season and with the stage of maturity at harvest $[3,4]$. This aspect has not been thoroughly examined in relation to processing of grass biomass for biorefining, but is important to take into account when assessing grass biomass as a feedstock for biofuels or biochemicals, since changes in composition may affect the processing and product yields to a high extent.

Another important aspect of a low cost lignocellulosic biomass supply is efficient storage and pre-processing methods [5]. The fact that grass is harvested at low dry matter (DM) typically of $18-20 \%$ DM makes dry storage at $>90 \%$ $\mathrm{DM}$ troublesome. Instead, through ensiling, grass can be stored at lower DM (20-50\%). Ensiling is the classical method of forage crop preservation optimised throughout the past two centuries to provide nutrient rich animal feed all year round [6]. Ensiling encompasses moist solid state anaerobic fermentation by lactic acid bacteria (LAB). The ensiling involves production of organic acids and a decrease in $\mathrm{pH}$ that consequently prevents growth of fungi, yeasts and bacteria which may otherwise decompose the carbohydrate structure in the biomass [7]. Three main factors influence the outcome of ensiling: (i) Biomass composition; (ii) biomass DM at ensiling, and (iii) the microbial community responsible for the fermentation [7].

Silage, the resulting biomass product of ensiling, has gained increased focus as a biomass feedstock for biofuel production in recent years [8]. The method poses several potential advantages as opposed to dry storage. The main advantages include (i) less dependence on dry weather conditions prior to harvest, hence, better harvest-timing, (ii) reduced biomass losses during harvest due to less handling steps and no loss from dust formation, (iii) no need for energy intensive drying, and (iv) possibilities of combined storage and pretreatment $[9,10]$. Combination of storage and pretreatment at ambient temperature and pressure holds considerable potential cost and energy savings compared to common and more severe pretreatments of chemical or physiochemical means [9].

Already 50 years ago Dewar et al. (1963) [11] showed that during ensiling, hemicellulose from perennial rye was hydrolysed initially by enzymes extracted from the grass and during longer storage (7-28 days) by means of acid hydrolysis at $\mathrm{pH}$ 4. These changes in biomass composition suggest that ensiling may be utilised as a biological pretreatment method for cellulosic biofuel and biochemicals production.

Four studies on ensiling as a biological pretreatment have reported results of cellulose conversion through enzymatic hydrolysis, all with the aim of producing energy carriers of either ethanol or biogas and the studies have consistently been reporting improved enzymatic saccharification for the ensiled biomass [9,12-14].

It is an obvious tenet that the grass biomass composition, $\mathrm{DM}$, and type of inoculum will influence the ensiling process as well as the silage quality, which in turn may affect the subsequent enzymatic cellulose convertibility. Nevertheless, in the currently available studies, the biomass and the conditions of ensiling have varied considerably, making it difficult to derive consistent rules for optimal ensiling for lignocellulose pretreatment. The objective of this study was to investigate the relations of three factors; biomass composition, initial DM, and addition of LAB inocula, upon enzymatic saccharification of cellulose after ensiling, using Festulolium Hykor as the grassland biomass. Festulolium Hykor is a crossbreed of the temperate grasses tall fescue (Festuca arundinacea) and perennial rye (Lolium perenne) developed by DLF TRIFOLIUM for high yield potential (18 tonne/ha) and high persistency throughout the season. However, the possible influence of the differences in the grass biomass composition of Festulolium Hykor across different harvests during a season, i.e. different cuts, on ensiling and silage quality has not been investigated.

\section{Materials and methods}

\subsection{Raw material}

The four cuts of the grass biomass, Festulolium Hykor (DLF TRIFOLIUM, Denmark), were harvested over the season 2011 (1st cut: 01.06.2011, 2nd cut: 06.07.2011,3rd cut: 20.09.2011,4th cut: 01.11.2011) from a DLF TRIFOLIUM demo plot, sized $1.5 \times 8 \mathrm{~m}$ and located in southern Zealand, Denmark $\left(55^{\circ} 20^{\prime} \mathrm{N}\right.$, $12^{\circ} 23^{\prime} \mathrm{E}$ ), with a HALDRUP F-55 harvester (Inotec Engineering $\mathrm{GmbH})$. The grass was collected right after harvest, cut to $2-5 \mathrm{~cm}$ pieces and split into four portions. Three of the portions were dried to different DM concentrations by means of different drying times at $25-30{ }^{\circ} \mathrm{C}$ (drying time ranged from 2 to $48 \mathrm{~h}$ ). DM content was monitored by use of a halogen DM analyser (Mettler Toledo HR83 Halogen) and exact measurements where done according to the standard procedure developed by the National Renewable Energy Laboratory (NREL) in the US [15]. The last portion of each cut was dried at $60{ }^{\circ} \mathrm{C}$ and stored as hay for raw material comparison in compositional analysis and enzyme hydrolysis (see below).

\subsection{LAB inocula}

The commercially available inocula LACTISIL Grass plus (GP) and LACTISIL CCM (CCM) (Chr. Hansen, Hørsholm, Denmark) were in freeze dried form, prepared individually in a $0.05 \mathrm{~g}$ $\mathrm{DM} / \mathrm{L}$ water suspension, and added to the grass samples for ensiling at a level equalling $4.0 \mathrm{mg} \mathrm{DM}$ inocula/kg fresh grass as according to [13].

GP consists of the lactic acid bacteria (LAB) Pediococcus pentosaceus and Lactobacillus plantarum, which are both homofermentative. CCM consists of pure Lactobacillus buchneri which is heterofermentative. Each grass sample was mixed carefully and thoroughly with each inoculum solution in a large plastic tray and samples were taken for final DM measurements prior to each ensiling.

\subsection{Ensiling}

The ensiling was carried out using a vacuum based plastic bag system according to [16]. A Variovac EK10 vacuum packaging machine (Variovac Nordic A/S, DK-7100 Vejle, Denmark) and $35 \times 45 \mathrm{~cm}$ vacuum bags were used to pack approx. $100 \mathrm{~g} \mathrm{DM}$ grass for each treatment. 


\subsection{Experimental design}

A duplicated $3^{2}$ experimental design was used to test the effect of different silage LAB inocula and different DM concentrations, and this was carried out on the four cuts of Festulolium Hykor harvested on 01.06.11, 06.07.11, 20.09.11, and 01.11.11. Three portions of grass at different DM were treated with two types of commercial inocula against treatment without inocula (only water added). All treatments were done in duplicates. A total of 72 bags were prepared and stored at room temperature. DM contents were 21,31 and $41 \%$ for the 1st cut, 23, 35 and $50 \%$ for the 2nd cut, 24, 28 and $43 \%$ for the 3rd cut and 22, 34 and $49 \%$ for the 4 th cut. Storage times were $46,48,49$ and 49 days for all samples from the respective cuts.

\subsection{Chemical analysis}

2.5.1. Quantitative analyses of monosaccharides and organic acids

After a two-step $\mathrm{H}_{2} \mathrm{SO}_{4}$ hydrolysis of the biomass according to [17] concentrations of carbohydrates

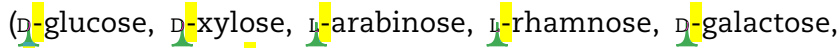
$\mathrm{n}$-mannose and $\mathrm{g}$-fructose) were quantified by High Pressure Liquid Chromatography (HPLC) (Shimadzu Corp., Kyoto, Japan) using an HPX-87P column (BioRad) (Hercules, CA; USA) and refractive index (RI) detection, at $80^{\circ} \mathrm{C}$ using water as eluent, $0.5 \mathrm{ml} / \mathrm{min}$. Organic acids (lactic-, formic-, acetic-, propionic, and butyric acid) were quantified by HPLC using a Biorad HPX-87H column (Hercules, CA; USA), RI detection, $63{ }^{\circ} \mathrm{C}$ and $4 \mathrm{mM} \mathrm{H}_{2} \mathrm{SO}_{4}$ as eluent, $0.6 \mathrm{ml} / \mathrm{min}$. Cellulose

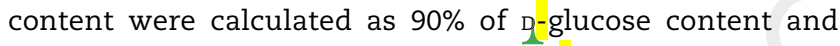
hemicellulose content as $88 \%$ of the g-xylose plus $88 \%$ of L-arabinose plus $90 \%$ of $\mathrm{q}$-galactose.

\subsubsection{DM/ash}

The DM and ash analyses were done according to NREL standard laboratory analytical procedures based on oven dry matter measurements [15]. Since silage biomass contains large amounts of volatile compounds, it is critical to correct the measured oven-DM (at $105{ }^{\circ} \mathrm{C}$ ) for loss of volatiles, to obtain the true DM. The measurements were therefore corrected using coefficients according to Ref. [18].

\subsubsection{Water extraction}

Aliquots of 0.3-0.4 g DM biomass from freshly disrupted silage bags were extracted in $10 \mathrm{ml}$ MilliQ $\mathrm{H}_{2} \mathrm{O}$ containing canamycin $(0.1 \mathrm{mg} / \mathrm{ml})$ to prevent microbial activity during extraction. The extraction samples were shaken for $2 \mathrm{~h}$ at $25{ }^{\circ} \mathrm{C}$ and $150 \mathrm{rpm}$. Extracts were analysed for sugars and acids by HPLC as described above. The biomass fibres were freeze dried and weighed to determine the amount of extractives. The levels of water and ethanol extractives were used as a measure of relative maturity in-between cuts [19].

\subsubsection{Weak acid hydrolysis of water extract} One step acid hydrolysis was performed on the extract to quantify the content of soluble oligomer carbohydrates. Extracts were autoclaved for $10 \mathrm{~min}$ at $121{ }^{\circ} \mathrm{C}$ with $4 \mathrm{w} / \mathrm{w} \%$ $\mathrm{H}_{2} \mathrm{SO}_{4}$. Derived monosaccharides were analysed by HPLC as described above.

\subsubsection{Ethanol extraction}

Lipophilic extraction was done by Soxhlet extraction in a reflux condenser for $6 \mathrm{~h}$ with 99\% ethanol. The amount of ethanol extractives, including volatiles, was defined as the mass of material lost through extraction.

\subsubsection{Lignin}

Lignin content of the extracted bio residue was assessed a two-step $\mathrm{H}_{2} \mathrm{SO}_{4}$ hydrolysis according to [17].

\subsubsection{Total N-determination}

The biomass samples were prepared for protein determination by wet milling in a Mannesmann wet mill (Remscheid, Germany) of a $1 \mathrm{~g} \mathrm{DM} / 1 \mathrm{H}_{2} \mathrm{O}$ solution to a particle size of $50 \mu \mathrm{m}$. Total nitrogen was measured using a kit from Hach Lange GmbH (Germany); Total Nitrogen LCK 138 (detection range: 1-16 $\mathrm{mg} \mathrm{N} \mathrm{L}^{-1}$ ). The protein content was calculated by multiplying the nitrogen content with 5.6 according to Ref. [20].

\subsection{Enzymatic hydrolysis}

The enzymatic hydrolysis was done at $1.6 \% \mathrm{DM}(\mathrm{w} / \mathrm{v})$ in a total volume of $25 \mathrm{ml}$ using $50 \mathrm{mM}$ citrate buffer at pH 5.0 with $0.4 \%$ w/w sodium azide. Commercially available cellulolytic and hemicellulolytic enzyme preparations, Cellic ${ }^{\circledR} \mathrm{CTec} 2$ and HTec2, from Novozymes A/S (Bagsværd, Denmark) were used in a $9 / 1$ ratio and added at $10 \%$ enzyme/substrate (w/w cellulose). Cellic ${ }^{\circledR} \mathrm{CTec} 2$ is a commercial cellulase preparation based on the cellulase complex produced by Trichoderma reesei containing at least the two main cellobiohydrolases EC 3.2.1.91 (Cel6A and Cel7A), five different endo-1,4ק-glucanases EC 3.2.1.4 (Cel7B, Cel5A, Cel12A, Cel61A, and Cel45A), $\beta$ glucosidase EC 3.2.1.21, and a $\beta$-xylosidase (EC 3.2.1.37) in addition to particular proprietary hydrolysis-boosting proteins. Cellic ${ }^{\circledR} \mathrm{HTec} 2$ mainly contains endo-1,4 3 -xylanase activity (EC 3.2.1.8), but also contains cellulase activity. Treatments were done during shaking for $72 \mathrm{~h}$ at $50{ }^{\circ} \mathrm{C}$. The enzymatic hydrolysis was done in triplicate and enzyme blanks were also analysed. Hydrolysates were analysed for glucose levels on HPLC and the glucose yield (GY) is presented per DM original grass biomass. Both ensiled and raw grass was extracted in $\mathrm{H}_{2} \mathrm{O}$ prior to the enzymatic hydrolysis to avoid interference from free sugars on the results for cellulose convertibility. Cellulose convertibility (CC) was calculated as the converted cellulose (derived from GY) divided by the original cellulose content (Equation (1)). A relative improvement ratio of the cellulose convertibility as compared to that for dry grass was also calculated to express the ensiling pretreatment effect (Equation (2)).

Cellulose convertibility $(\mathrm{CC})=(\mathrm{GY} \cdot 0.90) /$ Cellulose content

Relative improvementratio $=1+\left(\mathrm{CC}_{\text {silage }}-\mathrm{CC}_{\text {dry grass }}\right) / \mathrm{CC}_{\text {dry grass }}$

\subsection{Statistical evaluations}

One-way analyses of variances (one-way ANOVA): 95\% confidence intervals were compared as Tukey-Kramer intervals 
Table 1 - Composition of four cuts of Festulolium Hykor 2011. Numbers are presented as w/w\% of DM. The results in each row are grouped according to significance $(p=0.05 \%)$, where ' $a$ ' is significantly higher than ' $b$ ' and so forth.

\begin{tabular}{|c|c|c|c|c|c|c|c|c|}
\hline \multirow[b]{2}{*}{ Cellulose } & \multicolumn{2}{|c|}{ 1st cut } & \multicolumn{2}{|c|}{ 2nd cut } & \multicolumn{2}{|c|}{ 3rd cut } & \multicolumn{2}{|c|}{ 4th cut } \\
\hline & $27.5^{\mathrm{a}}$ & \pm 0.98 & $22.2^{\mathrm{b}}$ & \pm 0.56 & $25.6^{\mathrm{a}}$ & \pm 0.30 & $15.9^{c}$ & \pm 0.10 \\
\hline Hemicellulose & $18.1^{\mathrm{a}}$ & \pm 0.40 & $15.3^{\mathrm{a}}$ & \pm 0.39 & $16.2^{\mathrm{a}}$ & \pm 0.31 & $10.9^{\mathrm{b}}$ & \pm 0.04 \\
\hline Lignin & $10.4^{\mathrm{a}}$ & \pm 0.51 & $7.6^{\mathrm{b}}$ & \pm 0.33 & $9.4^{\mathrm{a}}$ & \pm 0.35 & $4.8^{\mathrm{c}}$ & \pm 1.16 \\
\hline Ash & $6.5^{\mathrm{c}}$ & \pm 0.24 & $7.2^{\mathrm{C}}$ & \pm 0.13 & $8.9^{\mathrm{b}}$ & \pm 0.02 & $11.5^{\mathrm{a}}$ & \pm 0.02 \\
\hline Ethanol extractives & $11.8^{\mathrm{c}}$ & \pm 0.54 & $16.3^{\mathrm{b}}$ & \pm 0.24 & $12.9^{c}$ & \pm 0.89 & $21.2^{\mathrm{a}}$ & \pm 1.98 \\
\hline Water extractives & $23.2^{\mathrm{b}}$ & \pm 1.59 & $29.3^{\mathrm{a}}$ & \pm 0.02 & $23.0^{\mathrm{b}}$ & \pm 1.44 & $29.1^{\mathrm{a}}$ & \pm 0.34 \\
\hline Soluble carbohydrates & $6.1^{\mathrm{b}}$ & \pm 0.03 & $10.3^{\mathrm{a}}$ & \pm 0.23 & $4.1^{\mathrm{b}}$ & \pm 0.06 & $4.6^{\mathrm{b}}$ & \pm 0.18 \\
\hline Soluble crude protein & $4.4^{\mathrm{b}}$ & \pm 0.02 & $5.2^{\mathrm{b}}$ & \pm 0.17 & $4.6^{\mathrm{b}}$ & \pm 0.17 & $10.7^{\mathrm{a}}$ & \pm 0.12 \\
\hline Total crude protein & $6.3^{\mathrm{b}}$ & \pm 0.07 & $8.0^{\mathrm{b}}$ & \pm 0.30 & $7.6^{\mathrm{b}}$ & \pm 0.19 & $21.1^{\mathrm{a}}$ & \pm 0.50 \\
\hline
\end{tabular}

calculated from pooled standard deviations (Minitab Statistical Software, Addison-Wesley, Reading, MA). Statistical significance of linear correlations was tested by the dose ${ }_{\complement}$ response F-test at 95\% confidence level [21].

\section{Results and discussion}

\subsection{Characterisation of grass}

\subsubsection{Composition and grass maturity}

The constituents of the chemical composition were grouped, according to the one-way ANOVA, in order to differentiate between the four cuts of grass (Table 1 ). The grouping revealed that 1st and 3rd cut had comparable compositions with all constituents except ash falling in the same group, while 2nd and 4th cut differentiated by having lower contents of cellulose and lignin and higher contents of extractives.

As grass matures the proportion of secondary cell walls increases and the fraction of non-structural cell contents decreases [22]. The total amounts of extractives are therefore a measure of relative maturity [19]. Thus, the four cuts represented different stages of maturity at harvest. 1st and 3rd cut had a similar and more advanced maturity than the 2nd cut, and the 4th cut having highest total extractives and lowest content of lignocellulosics, was the least mature at harvest. The higher content of extractives for the less mature 2nd and 4th cut, could be distinguished by a high concentration of water soluble carbohydrates (WSC) in 2nd cut (10 $\mathrm{w} / \mathrm{w} \% \mathrm{DM}$ ), and a high concentration of crude protein for 4 th cut (21 w/w\% DM) (Table 1). WSC does generally not directly correlate with maturity, but low production of WSC is often seen in late season growths [4]. Crude protein on the other hand, has been shown to decrease with advancing maturity for spring and summer growths, while late autumn growths usually have high, constant levels $[4,23]$. The compositional differences found between the four cuts of the grass were coherent with observations done at harvest. It was thus noted that 1st and 3rd cut both had met flowering stage whereas 2 nd and 4 th cut had not, and that the 4 th cut consisted primarily of leaves.

The four cuts of Festulolium Hykor in this study represent an example of the seasonal change that a biomass producer or biorefinery operator can expect when working with temperate grass. Seasonal change, representing the repeating annual variations in solar radiation, temperature, wind and rain, lead to natural differences between the different cuts. The growth season in 2011 (in Denmark) suffered from unusually high amounts of rain in the summer months (Table 2). The unusual rainfall influenced the timing of harvest, resulting in a slightly late 1st cut and a much delayed 3rd cut. In turn this resulted in a relatively high maturity of the 1 st and $3 r d$ cut as compared to the standard cutting strategy for the demo-plots at DLF Trifolium, which is optimised for feed quality of the grass biomass.

The maturity is, as reflected in the results (Table 1), a key parameter for the chemical composition. The exact harvest date is therefore important in grass managing systems. The increased proportion of secondary cell walls in mature grass increases recalcitrance and decreases cellulose convertibility. This effect is primarily due to increased lignin content and cross-linkages between lignin and structural carbohydrates $[24,25]$.

Keating and O'Kiely [4] studied the effect of maturity on different cuts of re-grown perennial rye grass and found that increased maturity decreased the DM digestibility in in vivo animal feed experiments, which indicated increased recalcitrance to microbial degradation. The compositions were in general comparable to previous published data of temperate grass like Festulolium Hykor [19]. The compositional relations between cuts of different maturity also match the general knowledge of grass growth and maturation [19].
Table 2 - Average weather conditions for Denmark 2011, when grass was harvested: spring (March, April, May), summer (June, July, August), fall (September, October). In parentheses: the average norm (1961-1990).

\begin{tabular}{|c|c|c|c|c|c|c|c|}
\hline & April & May & June & July & August & September & October \\
\hline Temperature $\left({ }^{\circ} \mathrm{C}\right)$ & $9.9(5.7)$ & $11.4(10.8)$ & $15.1(14.3)$ & $16.4(15.6)$ & $16.1(15.7)$ & $14.1(12.7)$ & $9.8(9.1)$ \\
\hline Rainfall (mm) & $16(41)$ & $54(48)$ & $75(55)$ & $113(66)$ & $132(67)$ & $92(73)$ & $61(76)$ \\
\hline Sun (h) & $253(162)$ & 239 (209) & 252 (209) & $171(196)$ & $150(186)$ & 135 (128) & 130 (87) \\
\hline
\end{tabular}




\subsection{Acid production during ensiling}

Each cut of grass responded differently to the experimental ensiling factors, giving four different patterns of organic acid production (Fig. 1). The organic acid concentration was highest for low DM treatments of the less mature grass samples (2nd and 4th cut), reaching around $10(\mathrm{w} / \mathrm{w}) \%$, but in both cases the organic acid production decreased considerably with higher DM. Ensiling of the more mature grass (1st and 3rd cut) resulted in less total organic acid production at low DM and the concentration decreased less significantly with DM.

\subsubsection{Water soluble carbohydrates}

The water soluble carbohydrates (WSC), which in temperate grass consist of fructose, glucose, sucrose and fructans [26], constitute the metabolic substrate pool for the ensiling. Sufficient WSC is therefore a prerequisite for successful silage fermentation. The concentration of WSC in the four cuts did not correlate directly with the production of organic acids. The significantly higher WSC level found in the 2nd cut gave the same levels of total organic acids as the 4th cut, which contained less than half the amount of WSC (Fig. 1). In the main fermentation phase of ensiling the bacteria rapidly consume readily available simple sugars as well as fructose from hydrolysed fructan which in temperate grasses is degraded by the plant enzyme fructan exohydrolase [27]. If the fermentation has not yet reached the stable anaerobic storage phase after the WSC are metabolised then other substances will act as substrate. Thus hydrolysed structural carbohydrates, primarily from hemicellulose, or amino acids from denatured proteins, will be the new source $[11,26]$. In the current study, the acid production varied differently in response to the amount of WSC available in the fresh grass. Some, namely the silage samples of 3rd and 4th cut, had a higher acid production than what could maximally be produced from the initial WSC content. For the 1st cut a higher acid production only occurred for the three low DM silage samples, and for the 2nd cut the amount of acids produced only exceeded the WSC content in fresh grass of the CCM inoculated, low DM silage sample. These samples have therefore, utilised other substrates like degraded hemicelluloses. The finding that the response to WSC levels was not consistent across the different cuts, underscored that the total composition of the grass rather than the content of WSC determined the outcome of the ensiling.

\subsection{2. $p H$ response}

In general, the $\mathrm{pH}$ dropped according to organic acid production, in particular according to the concentration of lactic acid, which is also in accordance with its lower pKa of 3.1. Low DM silage, especially for 2 nd and 4 th cut, reached the lowest $\mathrm{pH}$ during ensiling of around 4, whereas $\mathrm{pH}$ for the high DM silages reached levels around pH 5.5 for 2 nd and 4 th cut samples (Fig. 1). The latter results were in accordance with the lower production of organic acids. However, both lactic and acetic acid were in fact produced during the ensiling of the 4th cut at high DM, and moreover in comparable amounts to silage samples from the 1st cut which resulted in significantly lower $\mathrm{pH}$ values (around 4.6). Consequently grass from the 4 th cut had a higher buffering capacity than the other cuts. The

Fig. 1 - Organic acids and pH after ensiling; analysed in water extractions of silage grass. Four cuts of grass ensiled at three levels of DM (in percentage) and three inocula treatments Inocula: CCM: LACTISIL CCM (containing Lactobacillus buchneri), GP: LACTISIL GP (containing Pediococcus pentosaceus and Lactobacillus plantarum), water: no addition of LAB. 
reason for this is most likely the high content of crude protein in the 4 th cut (Table 1) that is known to facilitate buffer capacity towards silage fermentation [23].

\subsubsection{Inocula}

The type of inoculum caused significant differences in acid production in only 6 out of 12 cases within same cut and same DM (1st cut low DM; 2nd cut low DM; 2nd cut medium DM; and all three DM's of 3rd cut) (Fig. 1). For the 3rd cut the GP inoculum clearly improved the ensiling as measured by lactic acid production across the different DM concentrations. However, any such effect was not consistent across the four cuts, thus addition of an inoculum did not affect the silage fermentation under the experimental conditions used in this study. Lactic acid bacteria can be divided into two groups according to their carbohydrate metabolism, the homo- and the heterofermentative, the latter producing lactic and acetic acid, ethanol and carbon dioxide, the former producing only lactic acid [7]. Homofermentative ensiling is more efficient due to a more rapid $\mathrm{pH}$ drop and therefore faster preservation, while heterofermentative ensiling provides better resilience against spoilage of the silage [3]. It was thus somewhat surprising that the inocula did not affect the acid production of the ensiling to a larger extent despite the categorical differences in the types of microorganisms within the inocula. An explanation for the inconsistent effect of inoculum is obviously that the natural epiphytic organisms on the grass dominated the fermentation processes to a large extent. Accordingly, the inoculated amount may have been too low to dominate the silage fermentations.

\subsection{4. $\mathrm{DM}$}

$\mathrm{DM}$ at ensiling has been shown in several studies to be a main control factor affecting the microbial activity in the fermentation, and therefore affecting silage quality [28,29]. The results in Fig. 1 indicate a negative correlation between DM at ensiling and the production of organic acids during storage. Lactic acid concentration was found to decrease linearly with increasing DM $(p<0.05)$ (Fig. 2A). The acetic acid and propionic acid concentrations were also decreasing with increasing $\mathrm{DM}$ at ensiling, however much less than what was seen for lactic acid, and the linear correlations were not statistically significant $(p>0.05)$. Relatively large differences were found in the correlation between total organic acids and DM for the four cuts in-between (Fig. 2B) suggesting that chemical composition and thereby maturity and seasonal change had a huge impact on the results. The production of organic acid did, however decrease at higher DM for each cut (Fig. 2B) but linear correlation did only prove significant $(p<0.05)$ for the 4 th cut. The slope of the decrease was higher for the more immature 2nd and 4th cut compared to 1st and 3rd, however more data points are needed within each cut to describe the correlations further.

\subsection{Enzymatic hydrolysis}

\subsubsection{Dried grass}

Results of the glucose yield (GY), representing the amount of glucose released per biomass DM, and the cellulose convertibility (CC), representing the converted cellulose yield as
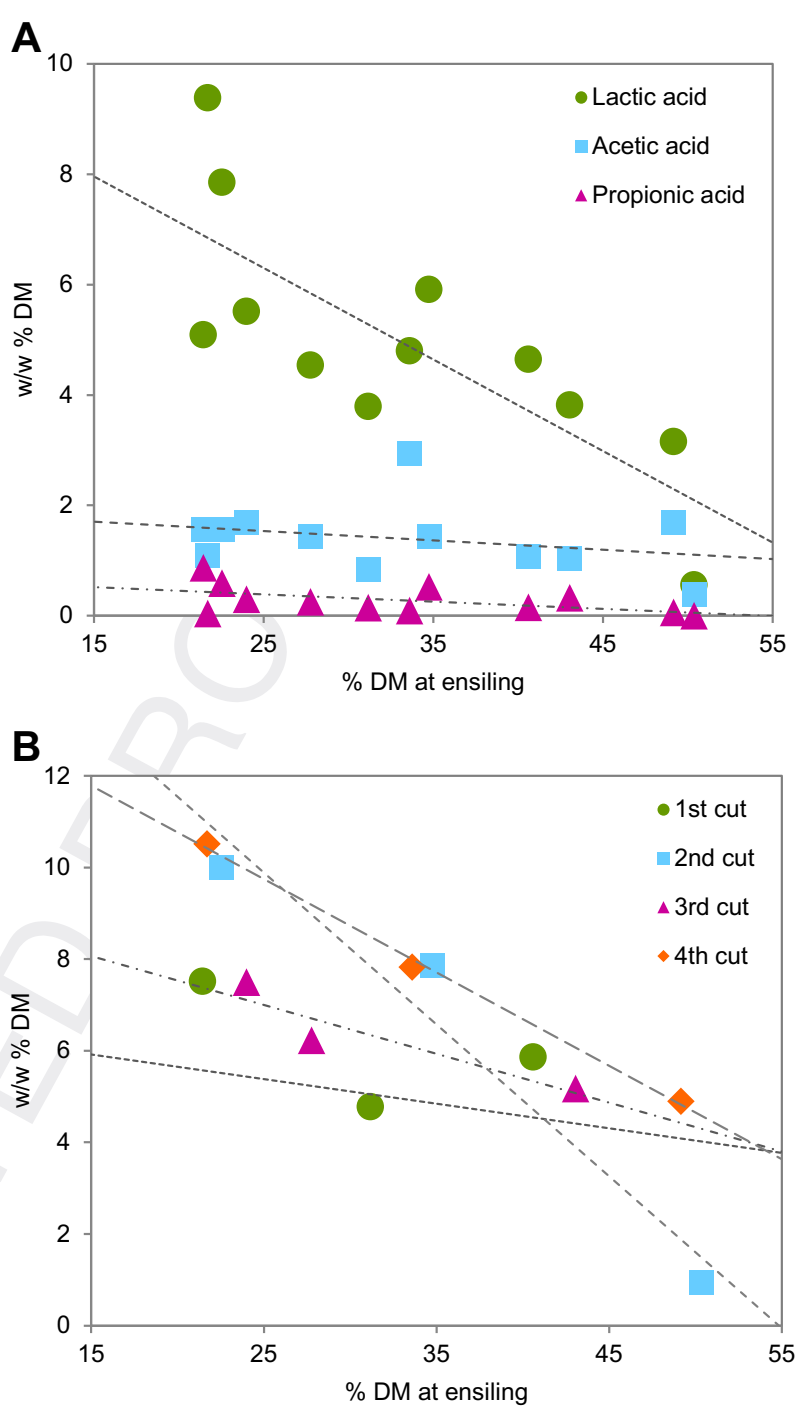

Fig. 2 - A. Main organic acids vs. DM; test of statistical significance of linear correlations $(p=0.05)$ : lactic acid is significantly correlated; acetic acid is not correlated; propionic acid is not correlated. B. Total organic acids vs. DM, for four cuts; test of statistical significance of linear correlations ( $p=0.05$ ): 1 st cut: no correlation; 2 nd cut: no correlation; 3rd cut: no correlation; 4th cut: significant correlation.

percentage of the total cellulose, were calculated for dry grass from each of the four cuts (Fig. 3A and B). The grass from 2nd cut gave the significantly (0.05) highest GY of $9.0 \mathrm{w} / \mathrm{w} \% \mathrm{DM}$ followed by 1st and 4th cut, which yielded 7.8 and $7.5 \mathrm{w} / \mathrm{w} \%$ $\mathrm{DM}$, and last 3rd cut with $5.5 \mathrm{w} / \mathrm{w} \% \mathrm{DM}$ (Fig. 3A). Thus a combination of less mature grass and relatively high cellulose content gave highest GY. Nevertheless, the CC results of the dried grass (Fig. 3B) show how the low cellulose content of the 4 th cut grass led to a higher CC for 4th cut than 2nd cut. Comparing the enzymatic hydrolysis of the four dried grasses showed that the mature grass of 1st and 3rd cut was more recalcitrant in terms of cellulose hydrolysis than the less mature 2 nd and 4 th cut. 


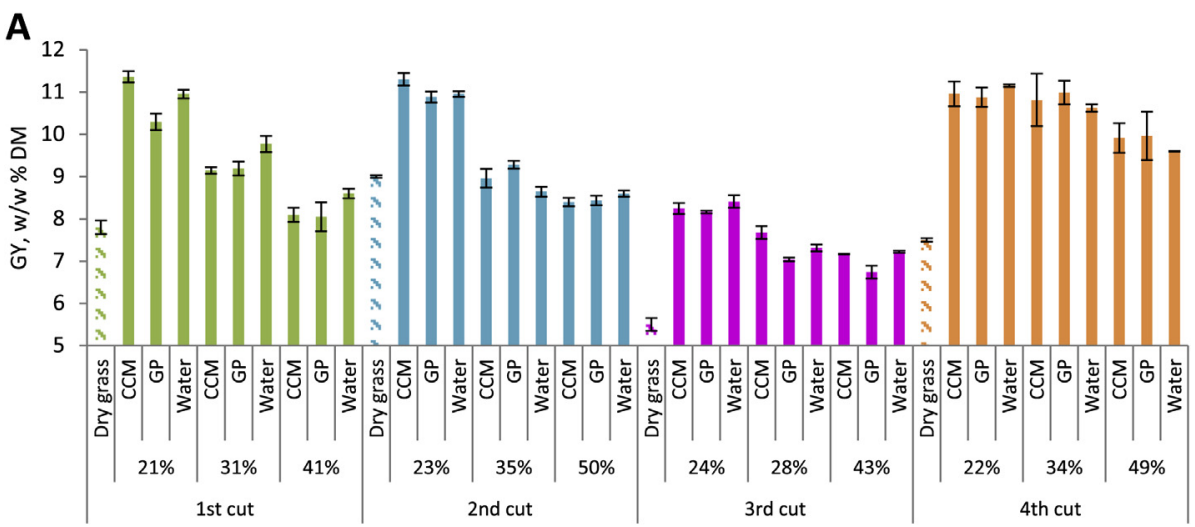

B

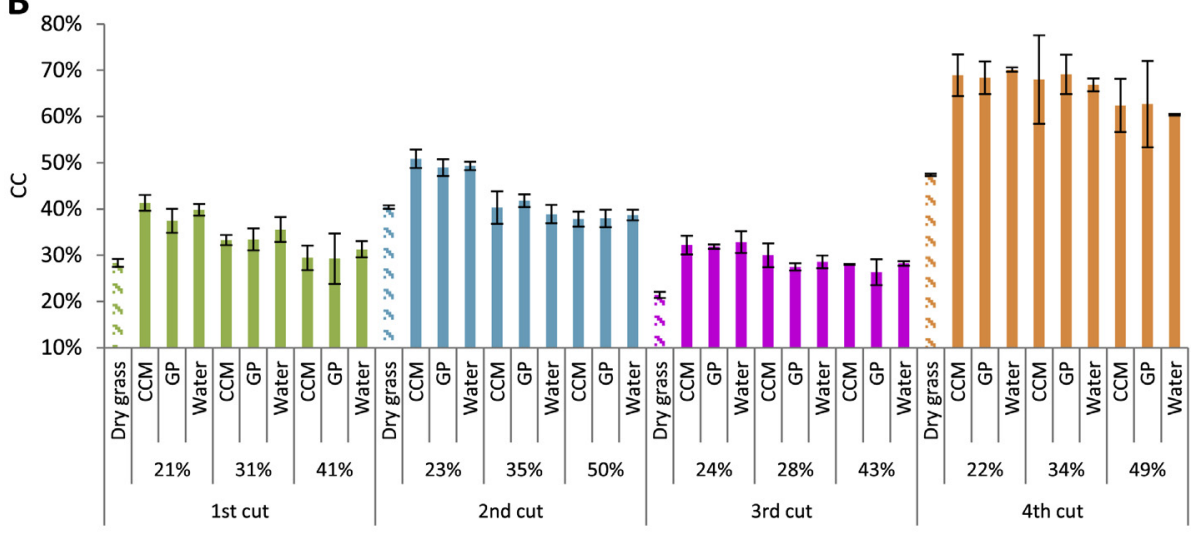

C

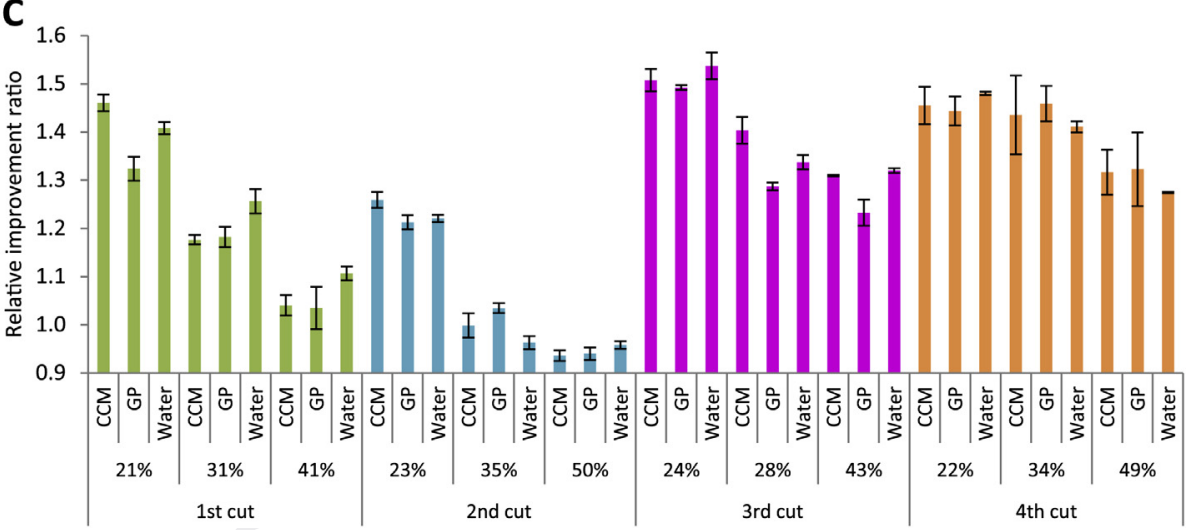

Fig. 3 - Enzymatic hydrolysis of dry and silage grass. A: Glucose yield (GY) w/w\% of DM; B: Cellulose convertibility (CC), \%; C: Relative improvement ratio: cellulose convertibility of silage compared to that for dried grass.

Both seasonal change and maturity contributed to the different chemical compositions of the four cuts, and even though the experimental setup did not include a detailed study of maturity, the fact that Festulolium Hykor was cut at different stages of maturity contributed considerably to the result of the study as a whole.

As seen in the current study cellulose content increased with advanced grass maturity, but likewise did lignin, consequently increasing lignocellulosic recalcitrance. The trade of high cellulose content is therefore related with decreasing cellulose convertibility in the enzymatic hydrolysis, thus resulting in less released sugars overall. This counter-relation suggests that there is an optimum stage of maturity for grass, where cellulose content and convertibility results in an optimal sugar release.

The findings related to maturity and enzymatic hydrolysis are in line with a study by Ding et al. [30] concerning the nanoscale architecture of plant cell walls and its direct influence on enzymatic degradation. In this study it was concluded that poor degradation of lignified cell walls was due to blocking of the enzymatic binding to the hydrophobic planar face of the cellulose microfibrils. Harvesting grass at an earlier growth stage, before a high degree of lignin deposition occurs during elongation, may therefore increase accessibility and productive binding of the cellulosic enzymes and increase degradation. Thus, maturity should definitely be a key 
parameter in grass managing systems for any lignocellulosic biofuel/biorefinery operation.

\subsubsection{Effect of ensiling on enzymatic hydrolysis}

The pretreatment effect of ensiling was measured by enzymatic hydrolysis and the GY and CC were compared to that of the dried grass (Fig. 3A and B). The GY results clearly show that ensiling had a positive effect on the sugar release by generally yielding higher amounts of sugar per $g$ biomass DM. For all cuts the low DM silage treatments gave higher GYs than the high DM silage treatments. However, as discussed above the compositional differences of the grasses caused deviations between the four cuts. The major differences between the cut were that ensiling of 4 th cut at medium and high DM also resulted in relatively high GYs as opposed to the other cuts, and 3rd cut silage generally resulted in lower GY, also at low DM. On the other hand, both the 1st, 2nd, and 4th cut resulted in similar maximum GYs, around $11 \mathrm{w} / \mathrm{w} \% \mathrm{DM}$ regardless of the GY of the appertaining dry grass. LAB inocula did not have a consistent and significant effect on GY, as it was also the case for the silage fermentation.

When translated into $\mathrm{CC}$, the picture changed due to the different cellulose content in the four cuts (Fig. 3B). 4th cut had the highest CC of $69 \%$ followed by 2 nd, 1st and last 4 th cut of $50 \%, 40 \%$, and $32 \%$, respectively, all at low DM and averaged over inoculum. In coherence with CCs of the dried grass the less mature cuts had higher CCs.

The CCs of the silage samples were compared to the CCs of the dried grass and a relative improvement ratio was calculated (Fig. 3C). Here it is even clearer that low DM gave better results than high DM across the four cuts. The highest improvements were found for 1st and 3rd cut of 1.40 and 1.42, respectively and averaged over inocula. 2nd and 4th also improved the CC but not by as much, 1.23 and 1.35 respectively (Fig. 3C). The only silage treatments which did not improve the enzymatic hydrolysis were at medium and high DM ensiling of 2 nd cut.

The enzymatic hydrolysis results matched the levels obtained in previous studies including CC of ensiled green biomasses such as clover-grass and reed canary grass $[12,13]$. Ensiling of these biomasses was found to facilitate a CC of $42 \%$ and $30 \%$ respectively, which in the case of clover-grass were an improvement ratio of 1.47 . This level matches the maximum relative improvements obtained for the low DM ensilage of 1st and 3rd cut in this study.

The results from the enzymatic hydrolysis correlated with the organic acid production in the silage treatments, and the data consistently indicated that high concentration of acids in the silage increased the pretreatment effect (Fig. 4A, B and C). The trend could however not reach statistical significance of a linear correlation, most likely because the variation in the level of hydrolysis between the four cuts diminished the statistical significance of the linear correlations.

The results of higher concentrations of hydrolysing organic acids produced at lower DM (Figs. 2 and 4) corroborate that the pretreatment effect of ensiling improves at lower DM. This also confirm the findings of previous research $[9,11-14]$ that the organic acids produced during ensiling promotes a gentle hydrolysis of lignocellulosic structures, which in turn appear to increase the access of the cellulosic enzymes to the
A

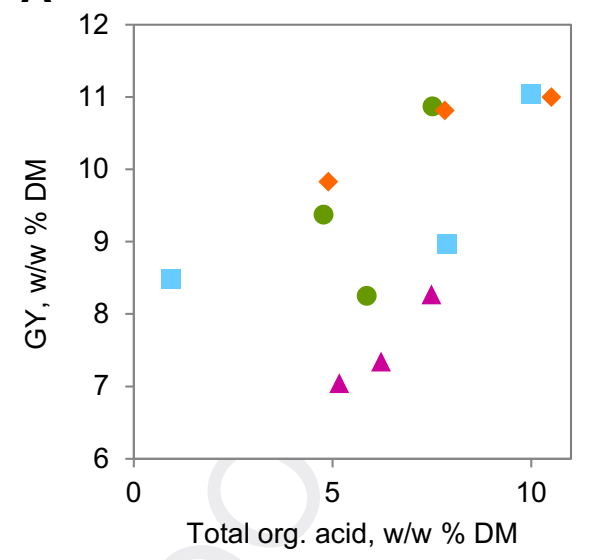

-1st cut

2nd cut

$\Delta$ rd cut

4 th cut

B

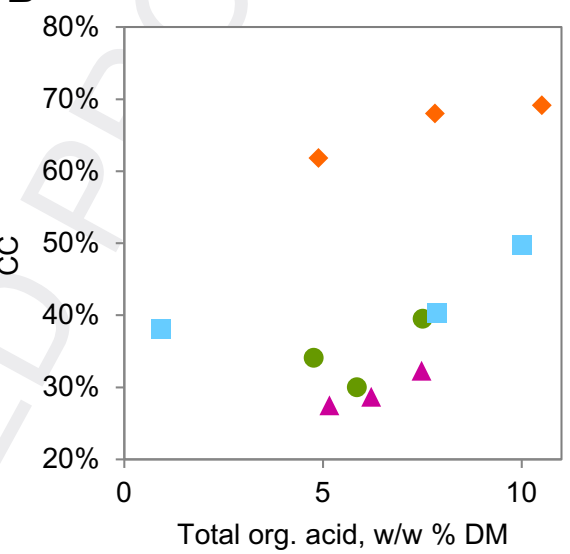

1st cut

2nd cut

$\Delta$ 3rd cut

$\checkmark 4$ th cut

C

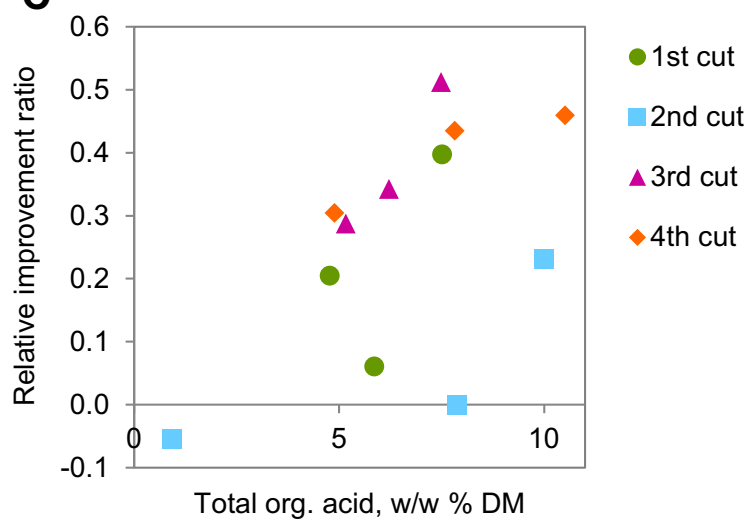

Fig. 4 - Enzymatic hydrolysis and total organic acid. A: Total organic acids vs. Glucose yield, w/w\% of DM; B: Total organic acids vs. Cellulose convertibility (CC), \%; C: Total organic acids vs. Relative improvement ratio, cellulose convertibility of silage compared to that for dried grass.

cellulose. Furthermore the present study demonstrates that maximising organic acid production in the silage, by ensiling at low DM, leads to a better pretreatment effect.

The level of GY's and CC's found for ensiling in this study, did however not match the performance of more severe pretreatment methods. Preliminary studies, by the authors, using hydrothermal pretreatment at $190^{\circ} \mathrm{C}, 10 \mathrm{~min}$ as according to 
[31], in itself gave close to total convertibility of cellulose (data not shown). The conditions of ensiling are apparently not severe enough to reach such high conversion. Opportunities for further optimisation could include addition of structure specific enzymes to the ensiling and/or development of better enzymatic blends adapted to silage grass. Further, more detailed studies of the fate of the cell wall materials during ensiling are required. Ensiling could also be combined with other more severe pretreatments and used as a prepretreatment. Ensiling is a promising method but can at this point not stand alone.

\section{Conclusions}

The abundant production, high annual yields, and low environmental impact of grasses like Festulolium Hykor, and the benefits of low DM storage simultaneously with a pretreatment effect, make ensiling of grass a promising technology for a future biobased production of fuels and chemicals from green biomass. The results from this study confirm and expand the knowledge on the subject of using ensiling as a biological pretreatment method.

- Ensiling improved cellulose convertibility compared to dry storage, through acid hydrolysis of the lignocellulosic matrix.

- Dry matter and chemical composition of the biomass affected the ensiling which affected cellulose convertibility.

- Low DM ensiling $(<25 \%)$ resulted in highest glucose yield and cellulose convertibility for all cuts of grass.

- The composition is largely determined by the maturity; less mature grass resulted in higher cellulose convertibility both with and without ensiling, due to the lower lignin content. However, less mature grass also has lower cellulose content. This suggests an optimum stage of maturity for grass, where cellulose content and convertibility results in an optimal sugar release.

\section{Acknowledgements}

We would like to acknowledge the technical support from Ingelis Larsen and Tomas Fernqvist and the scientific discussions in the BioEng group as a whole. The work was carried out within the EUDP project 'Silage pretreatment of green crops for 2nd generation bioethanol production' (Jr. no. 64010-0005) funded by the Danish Energy Agency.

\section{R E F E R E N C E S}

[1] Mandl MG. Status of green biorefining in Europe. Biofuel Bioprod Bior 2010;4:268-74.

[2] Prochnow A, Heiermann M, Plöchl M, Linke B, Idler C, Amon $\mathrm{T}$, et al. Bioenergy from permanent grassland - a review: 1. Biogas Bioresour Technol 2009;100:4931-44.
[3] McDonald P, Henderson N, Heron S. The biochemistry of silage. 2nd ed. Marlow, Bucks, UK: Chalcombe Publications; 1991.

[4] Keating T, O'Kiely P. Comparison of old permanent grassland, Lolium perenne and Lolium multiflorum swards grown for silage 4. Effects of varying harvesting date. Irish $\mathrm{J}$ Agr Food Res 2000;39:55-71.

[5] Shastri Y, Hansen A, Rodríguez L, Ting KC. Development and application of BioFeed model for optimization of herbaceous biomass feedstock production. Biomass Bioenergy 2011;35:2961-74.

[6] Wilkinson JM, Bolsen KK, Lin CJ. History of silage. In: Buxton DR, Muck RE, Harrison JH, editors. Silage science and technology. Madison, Wisconsin, USA: American Society of Agronomy, Inc. Crop Science Society of America, Inc. Soil Science Society of America, Inc.; 2003. p. 1.

[7] Muck RE, Harrison J. Silage science and technology. Madison, Wisc: American Society of Agronomy, Inc; 2003.

[8] Sieker T, Neuner A, Dimitrova D, Tippkötter N, Muffler K, $\mathrm{Bart} \mathrm{H}$, et al. Ethanol production from grass silage by simultaneous pretreatment, saccharification and fermentation: first steps in the process development. Eng Life Sci 2011;11:436-42.

[9] Chen Y, Sharma-Shivappa RR, Chen C. Ensiling agricultural residues for bioethanol production. Appl Biochem Biotechnol 2007;143:80-92.

[10] Emery IR, Mosier NS. The impact of dry matter loss during herbaceous biomass storage on net greenhouse gas emissions from biofuels production. Biomass Bioenergy 2012;39:237-46.

[11] Dewar WA, McDonald P, Whittenbury R. The hydrolysis of grass hemicelluloses during ensilage. J Sci Food Agric 1963;14:411-7.

[12] Digman MF, Shinners KJ, Casler MD, Dien BS, Hatfield RD, Jung HG, et al. Optimizing on-farm pretreatment of perennial grasses for fuel ethanol production. Bioresour Technol 2010;101:5305-14.

[13] Oleskowicz-Popiel P, Thomsen AB, Schmidt JE. Ensiling wet-storage method for lignocellulosic biomass for bioethanol production. Biomass Bioenergy 2011;35:2087-92.

[14] Pakarinen A, Maijala P, Jaakkola S, Stoddard F, Kymäläinen M, Viikari L. Evaluation of preservation methods for improving biogas production and enzymatic conversion yields of annual crops. Biotechnol Biofuels 2011;4:20.

[15] Sluiter A, Hames B, Hyman D, Payne C, Ruiz R, Scarlata C, et al. Determination of total solids in biomass and total dissolved solids in liquid process samples. NREL Technical Report 2008. NREL/TP-510-42621, www.nrel.gov/biomass/ analytical_procedures.html; December 2012.

[16] Johnson HE, Merry RJ, Davies DR, Kell DB, Theodorou MK, Griffith GW. Vacuum packing: a model system for laboratoryscale silage fermentations. J Appl Microbiol 2005;98:106-13.

[17] Sluiter A, Hames B, Ruiz R, Scarlata C, Sluiter J, Templeton D, et al. Determination of structural carbohydrates and lignin in biomass. NREL Technical Report 2011. NREL/TP-510-42618, www.nrel.gov/biomass/analytical_procedures.html; December 2012.

[18] Huida L, Vaatainen H, Lampila L. Comparison of dry-matter contents in grass silages as determined by oven drying and gas-chromatographic water analysis. Ann Agr Fen 1986;25:215-30.

[19] Hopkins A. Grass: its production and utilization. 3rd ed. Oxford, UK: Blackwell Science Ltd, Osney Mead; 2000.

[20] Mariotti F, Tomé D, Mirand PP. Converting nitrogen into protein-beyond 6.25 and Jones' Factors. Crit Rev Food Sci Nutr 2008;48:177-84.

[21] Berry DA, Lindgren BW. Statistics: theory and methods. 2nd ed. Belmont, CA: Duxbury (Wadsworth); 1996. p. 608-9. 
[22] Buxton DR, O'Kiely P. Preharvest plant factors affecting ensiling. In: Buxton DR, Muck RE, Harrison JH, editors. Silage science and technology. Madison, Wisconsin, USA: American Society of Agronomy, Crop Science Society of America, Soil Science Society of America; 2003. p. 199-250.

[23] Muck RE, O'Kiely P, Wilson RK. Buffering capacities in permanent pasture grasses. Irish J Agric Res 1991;30:129-41.

[24] Morrison IM. Changes in the lignin and hemicellulose concentrations of 10 varieties of temperate grasses with increasing maturity. Grass Forage Sci 1980;35:287-93.

[25] Hu F, Ragauskas A. Pretreatment and lignocellulosic chemistry. Bioenergy Res 2012;5:1043-66.

[26] Rooke JA, Hatfield RD. Biochemistry of ensiling. In: Buxton DR, Muck RE, Harrison JH, editors. Silage science and technology. Madison, Wisconsin, USA: American Society of Agronomy, Crop Science Society of America, Soil Science Society of America; 2003. p. 95-140.

[27] Merry RJ, Winters AL, Thomas PI, Muller M, Muller T. Degradation of fructans by epiphytic and inoculated lactic acid bacteria and by plant enzymes during ensilage of normal and sterile hybrid ryegrass. J Appl Bacteriol 1995;79:583-91.

[28] Van Ranst G, Fievez V, De Riek J, Van Bockstaele E. Influence of ensiling forages at different dry matters and silage additives on lipid metabolism and fatty acid composition. Anim Feed Sci Technol 2009;150:62-74.

[29] Zheng Y, Yates M, Aung H, Cheng Y, Yu C, Guo H, et al. Influence of moisture content on microbial activity and silage quality during ensilage of food processing residues. Bioprocess Biosyst Eng 2011;34:987-95.

[30] Ding SY, Liu YS, Zeng Y, Himmel ME, Baker JO, Bayer EA. How does plant cell wall nanoscale architecture correlate with enzymatic digestibility? Science 2012;338:1055-60.

[31] Thomsen ST, Jensen M, Schmidt JE. Production of 2nd generation bioethanol from lucerne - optimization of hydrothermal pretreatment. BioResources 2012;7:1582-93.

Please cite this article in press as: Ambye-Jensen M, et al., Ensiling as biological pretreatment of grass (Festulolium Hykor): The effect of composition, dry matter, and inocula on cellulose convertibility, Biomass and Bioenergy (2013), http://dx.doi.org/ 